\title{
Pharmacological Preconditioning with Gentamicin (G) Attentuated the Toxicity in LLC-PK1 and Acute Kidney Injury in Rats
}

\author{
Reis L.A. ${ }^{1}$, Carbonel A.A.F. ${ }^{2}$, Maganhin C.C. ${ }^{2}$, Simões M.J. ${ }^{2}$, Schor N. ${ }^{1}$ \\ 1. Nephrology Division, Department of Medicine, UNIFESP/ EPM, São Paulo, Brazil. \\ 2. Department of Morphology and Genetics, Federal University of São Paulo, UNIFESP -Brazil
}

Aminoglycosides are freely filtered across the glomerulus and then partially taken up by, concentrated in, and produce damage to proximal tubular cells. The renal injury induced by these drugs is related to their preferential accumulation in the renal cortex [1]. Ischemic or pharmacological preconditioning (PC) has been reported to be histo- and cyto- protective [2]. The aim of the present study was to evaluate the effect of $\mathrm{PC}$ with $\mathrm{G}$ on rat kidneys exposed to $\mathrm{G}$.

rVSMC harvest from Wistar rats were treated during 5 days either with water (CTL) or G (2mM). PC with G $2 \mathrm{mM}$ (PC-G) was performed during 2 to 72 hours. After PC-G the cells were treated again with $\mathrm{G}(2 \mathrm{mM})$ for 5 days $(\mathrm{PC}-\mathrm{G}+\mathrm{G})$. Cell viability was evaluated by acridine orange. Also Wistar rats were treated with daily intraperitoneal injections (i.p.) of $\mathrm{G}(40 \mathrm{mg} / \mathrm{kgBW})\left(\mathrm{G}_{10 \mathrm{~d}}\right)$ or water $\left(\mathrm{CTL}_{10 \mathrm{~d}}\right)$ for 10 days. Other group was PC with $\mathrm{G}\left(\mathrm{PC}-\mathrm{G}_{3 \mathrm{~d}}\right)$ or water $\left(\mathrm{PC}-\mathrm{CTL}_{3 \mathrm{~d}}\right),(40 \mathrm{mg} / \mathrm{kgBW}$, i.p.) for 3 days. After $P C$, they received $G$ daily for 10 days $\left(P C-C T L_{3 d}+G_{10 d} ; P C-G_{3 d}+G_{10 d}\right.$ ). Blood and urine were collected for creatinine and NO determination, the animals were sacrificed and the kidneys removed for histology.

Cell viability was decreased in $\mathrm{G}_{10 \mathrm{~d}}$ but they were significantly increased in $\mathrm{PC}-\mathrm{G}_{3 \mathrm{~d}}+\mathrm{G}_{10 \mathrm{~d}}$ groups. Rats treated with $\mathrm{G}_{10 \mathrm{~d}}$ or PC-CTL $3 \mathrm{~d}+\mathrm{G}_{10 \mathrm{~d}}$ presented a significant reduction of urinary $\mathrm{NO}$, increased plasma creatinine and urea; respectively. In PC- $\mathrm{G}_{3 \mathrm{~d}}+\mathrm{G}_{10 \mathrm{~d}}$ group, these biochemical effects were not observed. Kidneys showed an intensive marked KI67 and small caspase 3 and acute tubular necrosis (ATN) expression in $\mathrm{PC}-\mathrm{G}_{3 \mathrm{~d}}+\mathrm{G}_{10 \mathrm{~d}}$ group but differently, it was not marked for KI67 and intensive expression for caspase 3 and $A T N$ in $\mathrm{G}_{10 \mathrm{~d}}$ or PC-CTL $\mathrm{Cd}_{3 \mathrm{~d}}+\mathrm{G}_{10 \mathrm{~d}}$. Conclusion: PC-G for 3 days protected the animals against all these effects of G. Our data suggest that NO is involved in G nephrotoxicity and PC could be a useful tool to prevent it.

\section{References:}

1-Selby NM, Shaw S, Woodier N, Fluck RJ, Kolhe NV. QJM. 2009;102(12):873-80.

2- Pessoa EA,Convento MB, Ribas OS, Tristão VR, Reis LA, Borges FT, Schor N. Toxicol Appl

Pharmacol. 2011 May 15;253(1):1-6. 

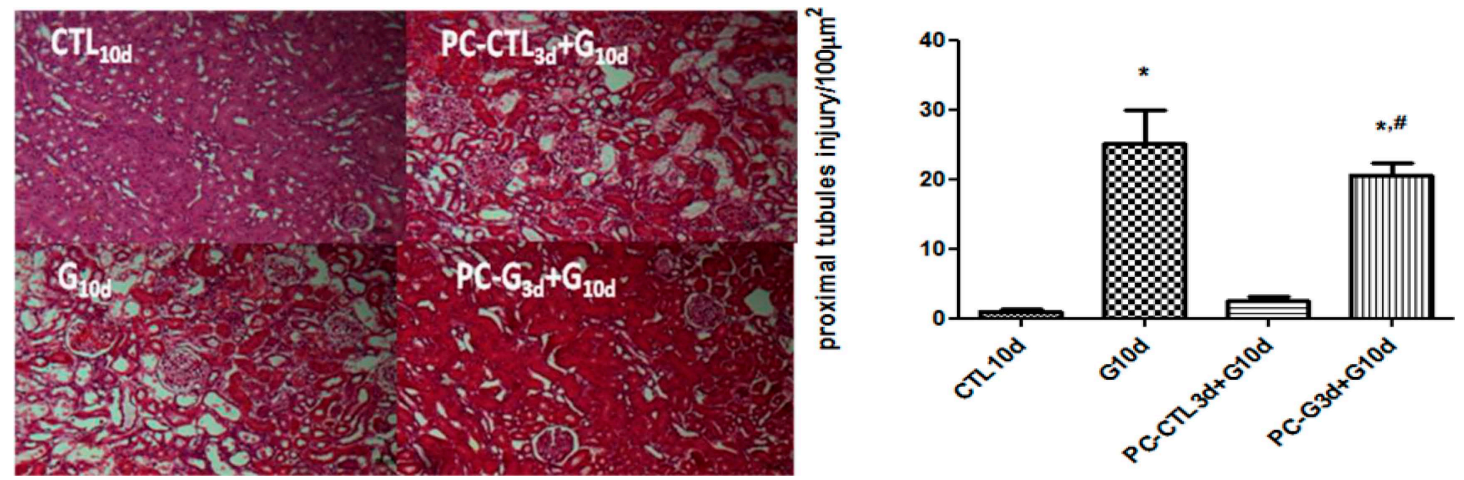

Figure 1: $\mathrm{HE}\left[\mu^{2}\right]$ in Wistar rats pre-conditioning with $\mathrm{G}$
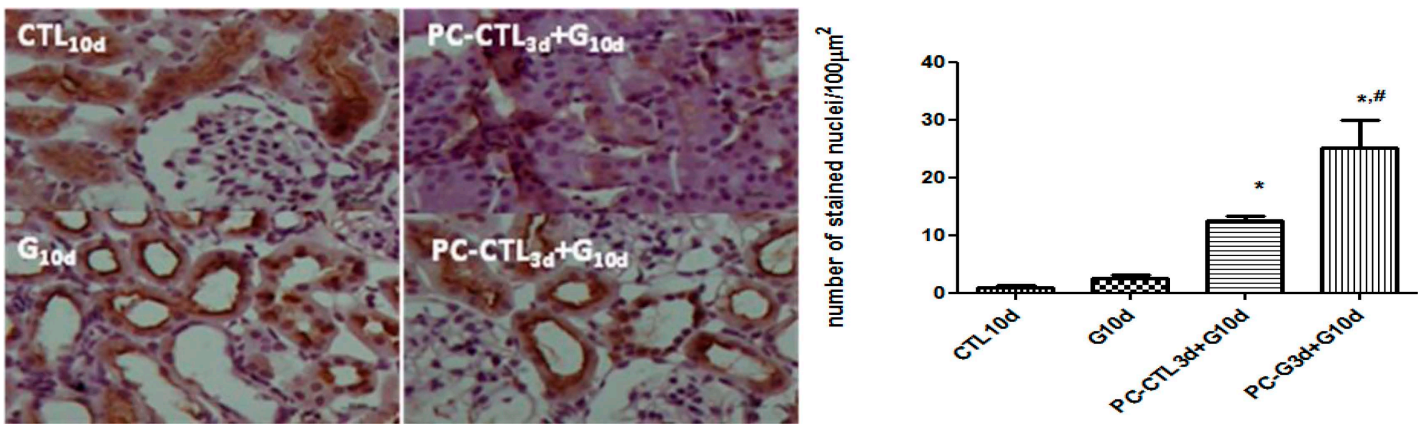

Figure 2: KI67[ $\left.\mu^{2}{ }^{2}\right]$ in Wistar rats pre-conditioning with $\mathrm{G}$
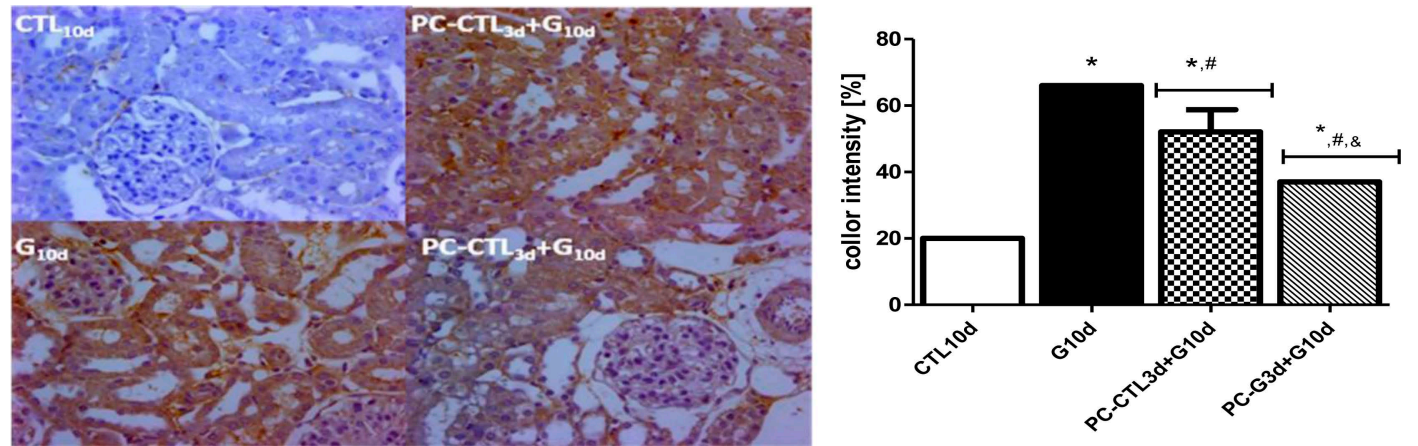

Figure 3: Caspase $3\left[\mu^{2}\right]$ in Wistar rats pre-conditioning with $G$ 